\title{
Neo-Weberian State - a Possible Life-Belt for Low-Developed Countries of Continental Europe
}

\author{
Cezara Fetescu \\ cezarafetescu@gmail.com \\ State Agrarian University of Moldova, Republic of Moldova
}

\begin{abstract}
This paper aims to analyze the empirical and normative foundations of NWS in order to determine the possible compatibility of this model with the administrative systems of poorly developed continental European (south-eastern European) countries. For this purpose, a comparative analysis of the two management models described in the specialized bibliographic sources was made, then, with the deductive reasoning, with the inductive type, the degree of novelty and viability of the NWS was established. It turned out that in the next 20-30 years public administration is bound to be friendlier to the state than the 1990s, and NWS seems to be one of the most interesting theoretical and normative answers to the question of how to lead or guide a complex society based on innovation where democracy has a complicated position.
\end{abstract}

Keywords: government models, public administration, New Public Management, NeoWeberian State

JEL Code: H83, H12

\section{Introduction}

The topic of administrative reform has reached in some countries a constant position in political discourse, and every year state services are affected by different sets of measures, with the aim of adapting structures to the evolution of the tasks entrusted to them. Starting from the evolutional way, it is appropriate to review the main management models of public organizations that have been going on since the very beginning: the bureaucratic model and New Public Management (NPM). Skeptics believe that the following models, designed to revolutionize administrative management should necessarily represent a mutation produced in time by the Weberian model, adapted to the conditions imposed by the changes produced in society, by the influence of NPM. Moreover, nowadays there is a new phenomenon in the public administration called the Neo-Weberian State (NWS), a model that substantially undermines the occupation of the New Government Public Administration (NPM). "Perhaps the most powerful element of NPM was that it was "new", a word that sounds ambitious in administrative reforms, because we cannot deny the fact that in modern society the emphasis is often fashionable. Today, the same can be said about NWS" [3]. Indeed, the idea of modernization itself should be clarified. What does "modern" really mean? Most of the time, public administration reform documents seem to be based on the extremely vague idea of modernization (for example, better service delivery). In any sense, in this context, the "modern" cannot mean anything specific, but "according to the times", "in accordance with the present situation". "Modern" in the sense of "the new" is certainly not just an ambiguity, but also a very ambivalent concept, according to the experiences of the twentieth century. Would a totalitarian change from democracy be better just because it is a new thing? The question arises involuntarily: what would today mean "modern", "fit for the weather", except for the term "fashionable"?

\section{Materials and methods}

In the following, we propose to establish what NWS actually represents: a model that is ambitious to change the paradigm imposed by NPM for the sake of "tendency" or a wellgrounded and adapted to the interference imposed by the times of crisis we live in, a clone of the old Weberian model, an NPM mutation, or a successful combination of the two models. 
For this purpose, we will thoroughly analyze the NWS principles and look at the premises behind the development of this model. We will establish its genesis to fundament or negate the importance assigned to it by contemporary researchers. In this sense, a comparative analysis will be made of the two management models described in the specialized bibliographic sources, then, by comparing the deductive reasoning with the inductive type will determine the degree of novelty and viability of the NWS.

\section{Results and discussions}

The alert rhythm of life, that mankind faces at the present stage, causes profound mutations in all areas of social life, obviously also in the public sector. Reconfiguration of the administrative system is also required by the need to align with global administrative performance trends, which implies that public management of any state embrace change and undergo a process of modernization that leads to performance.

Not only integration into the new international context raises the need for reform, but also the natural evolution of society that requires a considerable qualitative leap, in line with the fundamental objectives of governance.

Governments in developing countries, in particular, are interested in reforming bureaucracy. Bureaucratic reform refers to efforts modernize the state apparatus, which traditionally, in order to become more professional. Professional apparatus that is more efficient and more responsive to citizens. Reform of the bureaucracy is very important for developing countries because their bureaucracy is a major institutional machinery of government sector, but lack the capacity to facilitate the processes in an efficient and effective government.

Given that these objectives differ from state to state, depending on the current level of socio-economic development, cultural values and national specificity, this is only the point towards which all law-developed countries tend to reach the desideratum of moving towards citizen, who represents the primary capital of the public administration.

In order to answer this question, we will start from the concept of trajectory, which involves more than a trend. A trend is just a pattern of some data, and the trajectory, on the contrary, is an intentional pattern, it is a way someone is trying to adopt. It starts from an initial point (A) to a desirable place or desirable situation (B). Thus, a scenario consists of three basic elements: an initial state, a trajectory, and a future state.

„Scenarios may exist at different levels of specificity. They can be a simple set of vague ideas or guidelines, or they can develop into a strategic plan, with specified actions, chronologies and objectives. Scenarios are not always the same in the sense that one or more of their basics may be missing. For example, if only B is a picture of the future you want - but there is no clear specification for point A or trajectory, then it is a utopia" [8]. On the other hand, there may be a critique of the status quo (A) and the desire to go in a certain direction (trajectory), but to lack a well-defined picture of the final state of pursuit. This can be considered a kind of struggle with the waves, but there are, of course, conclusive proofs of good results in the field of managerial reform that undoubtedly do not leave hopeless states at this chapter.

To predict, we believe that the implemented scenarios, in which each of the three elements is clearly analyzed and described, are definitely an exception and not a rule in the public management reform. The real world is usually less orderly, with inadequately clear visions of the future, with inadequate analyzes of the status quo and partial, sometimes, conflicting or oscillating trajectories in different sequences of the administrative apparatus.

This has also been confirmed by the evolution of public sector reform, which has dismantled that "the trajectory of any scientific or political paradigm would be subjected to a cycle that begins with a period of growth and development, continuing with a period of domination, which then follows a phase of diminishing the potential of influence under the impact of competition of an emerging paradigm with the vocation to replace" [5]. Over time, public administration has evolved continuously, replacing the Weberian model with the neo-managerial one. Now is the time to ask whether or not the NPM has declined or is about to begin. 
Comparative analysis of bureaucratic model and NPM

\begin{tabular}{|l|l|l|}
\hline \multicolumn{1}{|c|}{$\begin{array}{c}\text { Comparison } \\
\text { criterion }\end{array}$} & \multicolumn{1}{c|}{ Bureaucratic model } & \multicolumn{1}{c|}{ NPM } \\
\hline $\begin{array}{l}\text { Political- } \\
\text { administrative } \\
\text { structures }\end{array}$ & $\begin{array}{l}\text { Public service as a great } \\
\text { institution } \\
\text { Large and complex departments } \\
\text { Centralization and hierarchical } \\
\text { coordination }\end{array}$ & $\begin{array}{l}\text { Universal service } \\
\text { Small administrative units } \\
\text { Decentralization and autonomy }\end{array}$ \\
\hline $\begin{array}{l}\text { Relationship with } \\
\text { politics }\end{array}$ & $\begin{array}{l}\text { Separation } \\
\text { Hierarchical authority }\end{array}$ & $\begin{array}{l}\text { Separation } \\
\text { Contractual authority } \\
\text { (dichotomy between political } \\
\text { and administrative) }\end{array}$ \\
\hline
\end{tabular}

Source: Own processing.

By comparing the bureaucratic model with the liberal model (Table 1), we find that the major discrepancies that ranked these two models as diametrically opposite poles are dictated by the relationship between the public administration and the political power as well as the complexity of the administrative structures, the coordinates to which NPM aims: decentralization, concentration and resizing public services" [2], which has facilitated paradigm shift.

If the Weberian model is considered a rigid one because it requires strict hierarchical centralization and coordination in relation to political power, the neo-managerial model assumes the inverse-decentralization and autonomy. A common feature for present authors is the location of bureaucracy in a position of total subordination to politics, and "seeking effective means of depoliticization becomes a primary objective in public management reform" [7]. But we have to mention that politicians are the ones invested with legitimacy, which is not omnipresent in the officials' situation.

Politicians approve the budget and they also have the opportunity to intervene in the internal structure of public institutions. "The current systemic crisis of the neo-liberal model of globalization financial capital regulation has, in the opinion of many countries, including the United States under President Barack Obama, led to a significant socio-political enthusiasm towards "state return" (including some instruments "Out-of-date" such as the nationalization of privately-owned companies faced with the danger of bankruptcy). Such tendencies contradict the neo-liberal weltanschauung of the "modest state" and greatly reduce the attractiveness of NPM solutions that have until recently enjoyed: ideas and values placed in an ethical horizon, strict regulations or arguments in favor of a socio-sustainable ecosystems are now firmly in the debate" [4].

So, the two political, bureaucratic powers must coexist together, even if they do not fully accept each other. As ugly and inefficient as politicians, they are the irreplaceable instrument by which the will of the people is represented.

Another major assumption of NPM is that unlike private enterprises, public institutions have differences and defects that are not due to their particular nature, but to a serious disease called "bureaucracy". Government institutions should therefore be healed. The recommended remedy should be based on the selection of methods and solutions that have proved to be satisfactory in the private environment and to be transposed into the public sector. The expected final result should develop into "de-bureaucratization". But it has already been demonstrated that reformism inspired by the private sector logic and methods, centered on improving the "3E" (economy, efficiency, effectiveness) that is characteristic of public services to produce a value-formoney ratio for citizens (customers) to be a coherent and stable dogma. 
Let us remember that the neo-managerial ambition of de-bureaucratization was based on a mixture of neo-conservative and ultraliberal ideology and common stereotypes of hostility towards "paperwork" and unnecessary officials. In the neo-liberal vision "the professionalization of public management consists in a wide process of attracting, selecting and creating within the public institutions a body of civil servants specializing in the field, applying modern methods, techniques and approaches" [1]. In the bureaucratic system, did not the professional play the main role?

Since the methods and solutions taken from the private environment were not exactly compatible with the institutional environment, "the bureaucratization of society increases due to the complexity of the governance process and, in particular, the desire to compensate for certain failures of the market mechanism". Moreover, "bureaucracy develops because of the needs that arise in society in the conditions of the development of the information society. It is capable of acquiring new areas of activity that would justify in some way its authority within the administrative system" [10].

"Time as a duration is an implacable force that transforms what could at one time be reform or innovation into "tradition" or inheritance. Even if we notice a trend of contemporary governments to state that state reform policies are permanent and never end, NPM precepts and prescriptions put in place for decades do not escape an aging process. Once exhausted, the corrosive and innovative potential of neo-managerialism tends to diminish itself" [4]. In this context, the notion of routine proposed by Weber can prove its explanatory virtues. Weber notes that routine changes the nature of charisma, which is subject to "traditionalizing, rationalization, or a combination of the two" [11]. By analogy, it can be said that neo-managerial innovations tend to become traditional features of the state embedded within its legal framework. "Preserving our skepticism about political discourses in vogue such as "treating citizens as a customer model "or" unnecessary governance due to the diffusion of information technologies" etc. It seems that NPM has left us as an inheritance on the one hand - an architecture, on the other hand - a set of tools" [4]. In this context, we refer to the fact that the NPM has paradoxically focused on organizational readjustments and rearrangements, a process called "play with organigrammes", these architectural rewards being one of the most tangible and lasting results of the recent period of administrative reform. Another valuable legacy is the rich repertoire of managerial instruments, unknown or used in the past, such as strategic planning, program budget, goal management, institutional transparency procedures, accreditation procedures, accountability procedures, indicators, e-government, one-stop-shops, benchmarking, multi-channel public service delivery, evaluation and self-evaluation. These tools are on the way of becoming a component part of local government, they are undergoing a process of embedding in the routines of public institutions that will ensure their survival and after NPM will be forgotten as anything that comes out of fashion.

Here it is appropriate to recall that NPM has spread as a repertoire of techniques presented systematically in international forums as "best practices". These have been assumed by policymakers from various corners of the world and transplanted into the respective public administrations, thus creating a sort of import-export circuit between national strategies and government reform or administrative modernization programs, without any conscious or explicit project of ideological hegemony be put into practice" [4]. There is a broad explanation in the public administration study to prove that "the implementation environment can generate significant differences in the effects of a particular management change" [8]. We are convinced that a conceptually identical or at least very similar reform develops differently in a national context (either sectoral or local) or another. "Such dissemination over time indicates that neomanagerial models and tools have evolved significantly, generated a variety of avatars, and undergone "acclimatization" processes according to the cultural context in which they were applied" [9].

"Two models are currently being promoted in the literature to replace or pursue reforms initiated by NPM: The Neo-Weberian State and the New Public Government. NWS is a model 
that competes with NPM, being considered a re-interpretation of Max Weber's theory in a European-specific approach, while New Public Governance (NPG) is part of the wider process of governance, a system that involves systems and processes responsible and gives an organization a clear direction" [6], which we are even tempted to consider as an NPM mutation (Fig. 1).

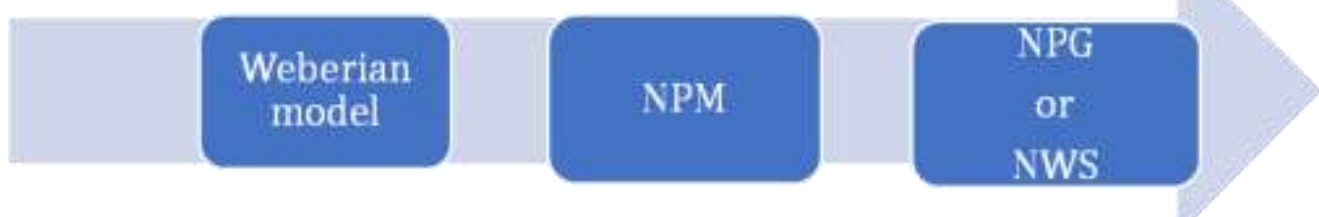

\section{Fig.1. Evolution of Public Government Reform Models}

Source: Own processing.

Instead, NWS is a model that is of interest to researchers from low-growth countries, as is our case. The Neo-Weberian term usually refers to the application of Weberian principles in a modern state or organization. The Neo-Weber label (NWS) was introduced by Christopher Pollitt and Geert Bouckaert in 2004 in the second edition of their book, "Public Management Reform: A Comparative Analysis" NWS refers to traditional (Weberian) administrative systems that are in the process of modernization, but preserves the distinctive features of public services.

NWS was initially conceived as a descriptive concept based on empirical evidence of public management reforms and was an attempt to find a common denominator in continental European developments. NWS describes an „omega, which is a destination, an ideal world to be achieved, a vision of a desired future" [9]. This omega situation might be ,a critique to the initial situation, status quo, or an alpha" [8]. NWS as an omega has a function as a vision of modern state employees, efficient, and friendly to citizens.

This new approach is a formidable metaphor describing a model that co-opts the positive elements of the NPM, but on a Weberian foundation, so both are asymmetric considered as replaced. Thus, elements of the Weberian construction concern: "the reaffirmation the role of the state as the main mediator for solutions to the new problems of globalization, technological, demographic and environmental threats; reaffirmation the role of representative democracy (at central, regional and local level) as an element of legitimacy within state apparatus; the reassertion of the administrative right to retention basic principles on citizens' relation, including equality before the law, legal security, as well as the availability of specialized legal control of the actions but also the preservation of the idea of a public service, with status, culture, terms and conditions distinct" [6].

NWS features are in moving process from an internal focus on bureaucratic norms to an external focus on the needs and wishes of citizens. The main way to achieve this is not the application of market mechanisms that have proven to be ineffective, but the creation of a professional quality culture; supplementing (not replacing) the role of representative democracy with a wide range of consultation devices and direct representation of the view of citizens' opinions; an upgrading of legislation to encourage it great concentration to achieve results, which is more appropriate than the correct observance of the procedure.

NWS as a conceptual map or summary description does not provide an analytical framework to analyze the reform experience in governments. However, based on the conceptual maps it can be developed a typology to classify, or specific theories to explain specific patterns and bureaucratic reforms trends.

NWS was conceived as an empirical-analytical model, not as a normative one and one of its creators, Pollitt, is quite self-critical about some of its aspects and neither this is not just about his criticism. However, NWS is currently, perhaps, the best explanatory model of what is happening in Europe and it helps significantly in the understanding of contemporary public administration. In fact, NWS is perfect for one innovation-based society, in contrast to NPM. Eventually, NWS 
seems to be the best available model for public administration in times of crisis, such as those which we currently live in. The return of the state to the economy means that our system cannot function without a truly competent and motivated public service as well that the reduction in public spending, at least in this area, is the worst idea that we can imagine.

In fact, one can even argue that the best hope, both for management crisis, and recovery later, is the return to a superior public service, capable, responsible, motivated, with a long-term focus among other Neo-Weberian institutions and really traditional Weberian institutions.

\section{Conclusion}

First, NWS as an empirical concept has a distinct background in the evolution of continental Europe and incorporates in many ways the European response to economic globalization. Thus, large reformation processes, while varying significantly between countries, relied on three fundamental premises, according to Bouckaert: to maintain the state as a primary framework, to use the law as a framework steering tool, and to exclude as far as possible experiments in the field of state, public administration and other important issues. Continental states accept more or less a strong state and try to modernize it, rather than minimize it (as opposed to the Anglo-American countries). Thus, "analyzing the empirical aspects of the NWS concept, one can conclude that NWS is a political response to some of the forces of globalization that are trying to keep the European social model directly threatened by the processes of globalization. The neo element preserves the main part of the traditional Weberian model and modernizes it (which can again take different forms specific to the context and country). NWS does not say whether it works, but it shows the political status and the incremental changes specific to continental Europe. Thus, it would not be right to call NWS a strategy (because the changes were incremental), but a political orientation. Empirically, the NWS base is the Weberian structure to which some NPM elements (rather than the Weberian elements added to the NPM) have been added "[3].

Secondly, while NWS has a clear empirical origin, the concept has gained a strong regulatory significance over the last few years for middle-income countries and less developed countries (e.g. the CEE), where it serves as a critical remark that before the modernization of the public administration (such as NPM reforms), a Weberian administrative apparatus that can be upgraded is needed. Indeed, many specialists believe that "if NPM reforms would work well, they would do so only on a strong Weber basis, which involves complementarity between Weberian public administration and NPM. Ironically, NPM seems to be unsuccessful without a traditional, solid, stable, and neutral bureaucracy. However, this has huge connotations for Central and Eastern Europe, and also for many countries in Southern Europe, where NPM-style reforms abound, while solid Weberian structures are hard to achieve. Indeed, NWS seems to be the perfect match for an innovationbased society, contrary to NPM. Innovation in the general interest, rather than that of an individual entrepreneur, is a matter of a successful innovation policy and who should implement it if not the administration?" [3] Simply, the innovation-based economy requires, relies on and needs a very competent, long-term public service to implement it, not so much without the social actors and without the public administration. As we are in the middle of the ICT paradigm, heading for a new moment, after collapse, and before heading for "synergy", the state and administration are called upon to assume the greatest tasks, and the anti-state climate of the period previous to ITC installation should end. In other words, the period of history that we are now entering, and this refers to the next 20-30 years, is bound to be much friendlier to the state than the 1990s, and NWS seems to be one of the most interesting theoretical and normative to the question of how to lead or guide a complex innovation-based society.

Thirdly, "since NWS is a concept with both empirical and clear normative aspects, it becomes obvious that the concept of modernization or change of the public administration itself (and NWS is part of this process) needs a serious theoretical development for avoid changing for the sake of change, as seems to have been the case for many NPM-inspired reforms" [3]. What is appropriate, however, depends on time and situation, and the problem is that the vast majority of claims in public administration documents use the term "modern" to designate a concept that is not exactly in line with times and circumstances. The strongest element of the NPM was probably 
that it was "new". It sounded extremely nice in administrative reforms, with emphasis being often fashionable. However, today this can be very well said about NWS. However, we believe that countries where democracy has a difficult position would applaud the idea of a bighly modernized state like NWS.

So, NWS might not be the way of the future, at least not everywhere, in any form and in all aspects, but the NPM is certainly an outdated pattern. Nothing has become clearer than the strong time of NPM. In this order, the criticism of NWS that it is too close to the NPM is justified to the extent that it co-opts NPM positive elements on a Weberian basis, namely both are asymmetrically substituted.

\section{References}

[1] Androniceanu, A., 2003, Tendințe noi în managementul public internațional și oportunitatea adaptării și implementării lor în Romania, Administrație și management public 1: 6-19.

[2] Androniceanu, A., 2007, Noul management public, un posibil model pentru reforma managementului public in sistemul administrativ din Romania, Administrație și management public 8: 52-57.

[3] Drechsler, W., Kattle R., 2009, Conclusion: Towards the Neo-Weberian State? Perbaps, but Cernainly Adieu, NPM! The NISP Acee Journal of public Administration and Policy, Vol. 1(2): 95-99.

[4] Eymeri-Douzans, J.-M., 2010, Statul actual: un bibrid post-managerialist sau neoweberian? Remarci liminare, cit.: Ionescu., A., Studia Politica: Romanian Political Science Review, 10(3): 413-423. bttps://nbnresolving.org/urn:nbn:de:0168-ssoar-448614.

[5] Hall., P., Policy paradigm, social lerning and the state, Comparative Politics, Vol. 25(3): 275-296.

[6] Moldovan, B-A., Performanța financiară in administrația publică locală și dezuoltarea economică a comunităților., 2018, Presa universitară Clujeană, 19-41.

[7] Negru, E., 2011, Administrarea și reformarea managementului public, Administrarea publică 3: 102-106.

[8] Pollit, Ch., Bouckaert, G., 2004, Reforma managementului public. Analiză comparativă., Epigraf, Chișinău, 19-52.

[9] Pollit, Ch., Bouckaert, G., 2008, Public management reform, cit.: Eymeri-Douzans, J-M., Les reformes administratives en Europe: Logiques managerialistes globales, acclimatations locales, Pyramides 15: 71-93.

[10] Varzari, P., Birocrația in contextul consolidării democrației: tendințe spre modernizare, Akademos 2(21): 54-58.

[11] Weber., M., 1978, Economy and society. An outline of interpretative sociology, University of California Press, Berkeley, 246-247. 